Журнал«Герспективитаінноваціїнаукиљ

(Серія «Гедагогіка», Серія «Гиихологія», Серія «Медицина»

№2(7) 2022

УДК 159.9:005.942]:316.362-053.2-056.3

https://doi.org/10.52058/2786-4952-2022-2(7)-832-840

Грицюк Ірина Михайлівна кандидатка психологічних наук, доцентка кафедри практичної психології та психодіагностики, Волинський національний університет імені Лесі Українки, вул. Потапова 9, м. Луцьк, тел.: (050) 539-28-67, https://orcid.org/0000-0001-6988-6012

Магдисюк Людмила Іванівна кандидатка психологічних наук, доцентка кафедри практичної психології та психодіагностики, Волинський національний університет імені Лесі Українки, вул. Потапова 9, м. Луцьк, тел.: (066) 520-16-40, https://orcid.org/0000-0002-5304-933

\title{
ПСИХОЛОГІЧНИЙ СУПРОВІД ТА КОНСУЛЬТУВАННЯ СІМ'Ї, ЯКА ВИХОВУС ДИТИНУ 3 ПОРУШЕННЯМИ РОЗВИТКУ (СИСТЕМНИЙ ПІДХІД)
}

Анотація. В нашій статті нами було викладено огляд теоретичних підходів до системного підходу допомозі сім'ї, яка має неповносправну дитину. Значення системного підходу важко переоцінити. Адже, дитина 3 неповносправністю не живе ізольовано, вона включена в сімейні відносини. Батьки, діти, брати та сестри також потребують підтримки суспільства та фахівців. Сім'я, яка опинилась в ситуації народження дитини 3 діагнозом, чи зіштовхнулась 3 важкими хронічними захворюваннями, так само, як і неповносправна дитина потребують підтримки, супроводу, консультування. Кожна дитина неповторна, кожне терапевтичне заняття неповторне. То ж ми здійснили аналіз існуючих моделей раннього втручання, а також зупинились на розгляді соціальноекологічної моделі сім'ї.

Дана модель, на нашу думку широко розкриває особливості взаємодії сім'ї, яка має неповносправну дитину 3 іншими соціальними інститутами та структурами. В теорії соціальної екології сім'я розглядається як система, яка не $\epsilon$ ізольованою, і зміни в будь-якій частині системи впливають на всі інші іiі складові.

Ми розкрили підходи зарубіжних колег, щодо співвідношення стадій розвитку сім'ї та стресових факторів, що відчувають сім'ї особливих дітей. Та визначили важливі життєві цикли, під час яких змінюються функції сім'ї та поведінка їі членів. Важлива увага приділена питанню розкриття реакцій сім'ї на порушення розвитку чи хворобу дитини. Такі сім'ї стикаються 3 великою кількістю труднощів. В Україні зокрема дуже велика кількість бар'єрів: це і недостатність в нашому суспільстві гуманізму та милосердя; непристосованість соціальної інфраструктури; низький рівень матеріального забезпечення і соціального системного обслуговування. Найбільш негативним та таким, що 
впливає на всю сім'ю, є бар'єр ізоляційний. Сім'ї з неповносправними дітьми прагнуть уникати контактів, замикаються у своєму горі. Системний підхід, допомога фахівців можуть змінити ставлення суспільства до дітей 3 неповносправністю, і такі сім'ї зможуть інтегруватись та жити звичним активним життям.

Ключові слова: системний підхід, сім'я, соціально-екологічна модель, життєвий цикл сім'ї, дитина з неповносправністю, сімейна система.

Hrytsiuk Iryna Mykhailivna Associate Professor of the Department of Practical Psychology and Psychodiagnostics, Lesya Ukrainka Volyn National University, Potapova St., 9, Lutsk, tel.: (050) 539-28-67, https://orcid.org/0000-0001-6988-6012

Mahdysiuk Liudmyla Ivanivna Associate Professor of the Department of Practical Psychology and Psychodiagnostics, Lesya Ukrainka Volyn National University, Potapova St., 9, Lutsk, tel.: (066) 5201-64-0, https://orcid.org/0000-0002-5304-933

\section{PSYCHOLOGICAL ACCOMPANY AND COUNSELING FOR A FAMILY RAISING A CHILD WITH DEVELOPMENTAL DISORDERS (SYSTEM APPROACH)}

Abstract. In our article, we have provided an overview of theoretical approaches to a systematic approach to helping a family with a disabled child. The value of a systems approach is difficult to overestimate. After all, a child with a disability does not live in isolation, it is included in family relationships.Parents, children, siblings also need the support of society and professionals. A family that is in a situation of childbirth with a diagnosis or faced with severe chronic diseases, as well as a disabled child need support, support, counseling. Every child is unique, every therapeutic lesson is unique. We also analyzed the existing models of early intervention, and also focused on the socio-ecological model of the family.

This model, in our opinion, widely reveals the peculiarities of the interaction of a family with a disabled child with other social institutions and structures. In the theory of social ecology, the family is seen as a system that is not isolated, and changes in any part of the system affect all its other components.

We have revealed the approaches of foreign colleagues to the relationship between the stages of family development and stressors experienced by families of special children. And identified important life cycles during which the functions of the family and the behavior of its members change. Important attention is paid to the issue of disclosing the family's reactions to developmental disorders or illness of the child. Such families face many difficulties. In Ukraine, in particular, there are a large number of barriers: this is the lack of humanism and charity in our society; inadequacy of social infrastructure; low level of material support and social system services. The most negative and affecting the whole family is the barrier of isolation. Families with children with disabilities seek to avoid contact, locked in their grief. A 
systematic approach, the help of specialists can change society's attitude to children with disabilities, and such families will be able to integrate and live a normal active life.

Keywords: system approach, family, socio-ecological model, family life cycle, child with disabilities, family system.

Постановка проблеми. В останні десятиліття увага науковців та практикуючих фахівців була зосереджена на визначення того, як поява дитини 3 особливими потребами впливає на сім'ю загалом, i, власне, як характеристики сім'ї, можуть впливати на розвиток дитини та ії психологічне благополуччя та розвиток. Загальне усвідомлення, що «неповносправна динина як така не існує сама собою, насправді $є$ сім'я, в якій є дитина 3 неповносправністю» [9], у всьому світі привело до того, що розвиваються нові моделі надання послуг, які включають у себе не лише дитину, а й всю сім'ю. Перехід від біомедичної моделі реабілітації до сімейно-центрованих програм був спричинений глибоким усвідомленням, що неповносправність дитини - велике випробовування для сім'ї [3].

В світі, зокрема в США, з 1985 року знайшли поширення сімейні програми раннього втручання з використанням сімейно-орієнтованої допомоги. В першій половині XX століття почали створювати та використовувати такі моделі, які активно включають в процес лікування не лише дитину, а й інших членів сім'ї.

Turk i Kerns (1985) стверджували, що багаточисленні дослідження щодо впливу хвороби на сім'ю, та про роль сім'ї у відновленні здоров'я та протидія хворобі ще не інтегровані у відповідні дисципліни. Тому інтерес до сім'ї та вплив на неї хронічних захворювань одного з ії членів значно підвищився останнім часом. Тому так важливо спеціалістам, які працюють в даній сфері розуміти сімейну динаміку, і динаміку сім'ї з особливою дитиною [5].

Аналіз останніх досліджень і публікацій розкриває такі важливі теми для розуміння даної проблематики, як вплив стресу на функціонування сім'ї (Crnic, Friedrich, Greenberg, 1983; Wikler, 1981). А також вплив на сім'ю соціальної підтримки і соціальних зв'язків (Holroyd, 1974; Kazak, Marvin, 1984). Роботи Е. Тернбулл [11]та інших авторів літератури для спеціалістів, що розробили зручну систему понять, об'єднавши конструкти сімейних систем та інформацію про сім'ї, в яких є діти 3 особливими потребами. Роботи, науковців, що стосуються особливостей першого переживання, коли батьки дізнаються про діагноз своєї дитини (Roberts, 1997; Duncan, 1977; Blasher, 1984). Дослідження Baxter (1986), що стосувались впливу поведінкових проблем неповносправної дитини, адже такі проблеми виникають у родинах, де ростуть діти з аутизмом, гіперактивним розладом, 3 дефіцитом уваги та іншими формами неповносправності [7]. Також у своїй роботі ми спирались на роботи відомих ерготерапевтів, зокрема У. Кислінг, які допомагають налагодити діалог з дітьми, авторка ділиться теоретичними та практичними аспектами роботи щодо розвитку з позиції налагодження взаємозв'язків з оточуючими, тощо. 
Мета статті проаналізувати підходи теорії сімейних систем в родинах, де $\epsilon$ неповносправна дитина. Визначити труднощі, 3 якими стикаються члени родини. Та намітити шляхи допомого таки сім'ям, як заради їх ефективнішого функціонування та подолання проблем 3 самооцінкою, відчуттям провини, страхам, соціальним стигмаціям тощо, так, і заради, ефективнішого функціонування неповносправної дитини та їі соціалізації.

Виклад основного матеріалу. Мінухін (1974) зумів дати визначення інтерактивної природи сім'ї, він зазначав, що індивід впливає на своє оточення, і сам піддається впливу в епізодах взаємодії; він реагує на стреси в інших областях системи, до якої він адаптується; його дії можуть здійснювати значний вплив на стрес, який відчувають інші члени системи. Індивіда можна розглядати, як підсистему, або частину системи, однак неможна залишати без уваги систему вцілому. Все, що зачіпає одного з членів сім'ї, впливає на усіх інших.

Carter E., McGoldrick у своїх працях зазначали (1980), що фізичне, соціальне та емоційне функціонування членів сім'ї глибоко пов'язані, і на зміни в одній частині системи, відгукуються зміни в іншій.

Е. Тернбулл та її колеги сформулювали цілу концепцію сім'ї, яка допомагає зрозуміти динамічну природу функціонування сім'ї, ¥ї характерологічні особливості, та спробували примінити цю теорію до вивчення сімей, в яких $€$ діти з порушенням розвитку [11]. Реакція сім'ї на порушення розвитку або хворобу дитини в основному визначається, на думку авторів, ідеологічним стилем сім'ї, однак, і така дитина може вплинути на цінності сім'ї також. Хронічні захворювання та порушення розвитку не обмежуються ні расовими, ні культурними, ні соціально-економічними бар'єрами, народження такої дитини можливе в будь-якій родині. В такому випадку сім'ї доведеться зіткнутись не лише з тим, що означають для них порушення розвитку у дитини психологічно та практично, але й переглянути своє ставлення до людей 3 обмеженими можливостями [4].

О. Романчук також зазначає, що однією 3 головних характеристик сучасного бачення реакції сім'ї на неповносправність дитини $є$ системне розуміння сімейної динаміки. Теоретично проаналізувати усю складність системних реакцій доволі важко, оскільки в кожному конкретному випадку зміни в динаміці сім'ї зумовлені неповторною сукупністю індивідуальних чинників, дослідити вплив кожного окремого чинника і його зв'язок 3 тими чи іншими змінами також дуже складно [3].

Та фахівцям важливо пам'ятати та враховувати, що дитина 3 порушеннями розвитку не перебуває в ізоляції. Як і всі люди, вона живе в контексті сім'ї, яка також має свої підсистеми, рівень згуртованості, здатності до адаптації та особливості комунікації. Всі ці аспекти можуть порушуватись 3 появою неповносправної дитини. Адже, дуже часто дитина з порушенням розвитку, особливо, якщо порушення дуже складні, може багато вимагати від сім'ї, при цьому майже нічого не даючи взамін [2]. 
Для жінки народження неповносправної дитини часто $є$ особливою особистою кризою. Біологічна роль жінки виносити та народити дитину стає підгрунтям до відчуття особистої відповідальності за стан дитини, а у випадку народження неповносправної дитини - до відчуття власної вини, та власної материнської неповноцінності. Featherstone, зазначає, що ціла культура підтримує матір в переконанні, що ії діти - це відображення того, що вона в них вклала. Тому відчуття провини, яке переживає жінка, може призвести до важких психосоціальних наслідків (гіперопіка та формування симбіотичного зв'язку; обділення увагою інших членів родини; занедбання власних інтересів та потреб розвитку; вседозволеність та непослідовність у вихованні тощо) [3].

Більше того, особлива дитина може змінити самоідентичність сім'ї, знизити iii здатність до заробляння коштів, звузити можливості відпочинку та соціалізації, вплинути на кар'єрні рішення. Тому навіть, успішно функціонуюча сім'я, при народженні неповносправної дитини, повинна володіти певною гнучкістю, відкритістю до змін та мати ресурс до супротиву труднощам [4].

А. Адлер писав у своїх роботах, що дитина, це i картина, і художник. Починаючи з першого крику, невпевнених рухів, вона прагне поводити себе так, що дорослі хочуть опікати, взаємодіяти. Кожен такий епізод соціальної взаємодії дає дитині безліч можливостей для навчання, а іiі реакції на поведінку дорослих, викликають подальшу взаємодію [1]. Та дитина 3 неповносправністю може і не відгукуватись на спроби рідних та близьких налагодити з нею контакт; ії зовнішній (фізичний) вигляд, поведінка може лякати чи викликати відразу, страх, неприйняття тощо. Що може впливати на формування прив'язаності.

Поява на світ дитини 3 неповносправністю буде впливати i на функціонування сім'ї та на проходження життєвих циклів. Переходи від однієї стадії до іншої можуть бути джерелом сильного стресу. AP. Turnbull та інші (1986) співвіднесли стадії розвитку сім'ї зі стресом, який переживають родини особливих дітей. Вчені визначили основні стресові фактори, які відповідають певній стадії за Olson (1984):

1. Народження дитини, немовлячий вік, дошкільний вік. Постановка точного діагнозу; емоційне пристосування; повідомлення про порушення розвитку у дитини іншим членам сім'ї.

2. Шкільний вік. Прийняття рішення про звичайне або спеціалізоване навчання; вирішення проблем, що пов'язані з реакціями на дитину ії одноліток; організація навчання та відпочинку дитини.

3. Підлітковий вік. Емоційне пристосування до хронічної та невиліковної природи порушень; вирішення проблем пов'язаних 3 сексуальністю дитини, з іiі ізоляцією від одноліток; створення планів на майбутнє дитини, вибір можливої професії.

4. Дорослішання. Емоційне пристосування до догляду за дорослою дитиною; прийняття рішення щодо проживання дитини (вдома чи в спеціалізованому закладі); вирішення проблем, пов'язаних 3 обмеженою кількістю можливостей для соціалізації та спілкування. 
5. Постбатьківська стадія. Перегляд відносин 3 шлюбним партнером (якщо дитина живе поза домом); взаємодія 3 працівниками спеціалізованого закладу, де проживає дитина; створення планів на майбутнє [10].

На сьогодні відомі такі моделі розвитку дітей $з$ неповносправністю та врахування особливостей допомоги сім'ї, яка має дитину 3 особливими потребами: соціально-екологічна модель, Денверівська модель раннього втручання для дітей з аутизмом С. Дж. Роджерс та Д. Доусон, DIR/Floortime модель терапії дітей 3 аутизмом, яка враховує особливості розвитку, індивідуальні особливості та систему відносин (С. Грінспен); терапія розвитку відносин - сімейно-орієнтована поведінкова терапія, в основі програми поступовий розвиток природніх емоційних відносин (С. Гатстен); SCERTS модель навчання дітей з аутизмом через розвиток навичок соціальної взаємодії, емоційної регуляції, підтримки і розвитку відносин (адаптація середовища та створення інструментів, які допомагають навчанню (візуальна комунікація, письмовий розклад, сенсорна підтримка) [1].

Основна ж ідея соціально-екологічної моделі, будується на взаємодії між складовими частинами системи, зокрема між власне сім'єю та іншими соціальними структурами. Екологічне оточення сім'ї надає ій ресурси, що необхідні для життя, створює системи життєвої та соціальної підтримки; підтримка сім'ї особливої дитини іншими сім'ями, що знаходяться в подібній ситуації через створення груп підтримки, надання сім'ї допомоги від різноманітних держустанов.

В теорії соціальної екології сім'я розглядається як система, яка входить в безліч інших суспільних систем. Основна думка теорії соціальної екології: якщо ми прагнемо змінити чиюсь поведінку, в даному випадку, поведінку сім'ї необхідно змінити умови існування сім'ї, і що важливо, на дитину або на сім'ю в цілому можуть впливати події, в які ці люди навіть не включені (умови роботи батьків, стан місцевої економіки, кризи суспільні тощо).

Підсистеми соціально-екологічної моделі включають в себе:

- мікросистему -набір патернів поведінки, ролей та міжособистісних відносин, які існують в сім'ї;

- мезосистему - включає в себе близьке оточення сім'ї та поле ії активних дій (лікарі та медичні працівники, родичі, друзі та сусіди, знайомі та колеги, інші батьки, місцева громада тощо);

- екзосистему - сюди входять умови, на які сім'я не може активно впливати, але ці умови впливають на сім'ю (ЗМІ, система охорони здоров'я, соціальні служби, освіта);

- макросистему - яка відображає прийняті в суспільстві цінності (етнічні, культурні, релігійні та соціально-економічні).

Порушення розвитку у дитини можуть здійснити ізоляційну дію на сім'ю. особливо гостро це може відчуватись під час переживання певних життєвих циклів, коли батьки з новою силою відчувають тривогу та печаль. Fewell (1986) визначає шість особливо важких періодів для батьків особливих дітей: 
1. Зіткнення з порушеннями у дитини (виявлення серйозної чи хронічної проблеми часто викликають кризові переживання і впливають на всю сім'ю). Безпосередні реакції батьків - потрясіння, глибоке розчарування, тривога, депресія. Сором, страх нерозуміння, часто, змушують сім'ю ізолюватись, хоча саме в цей період їй необхідна психологічна та соціальна підтримка. Сім'я переживає важку травму, перебуваючи в постійному стресі.

2.Раннє дитинство, це період, коли сім'я зіштовхується 3 хронічною природою порушень, і з тим, які труднощі це несе .для дитини і для її близьких. Тип і рівень порушень можуть відігравати ключову роль у сприйнятті та поведінці сім'ї.

3.Шкільний вік. Особлива проблема розпочинається тоді, коли батьки розуміють, що їх дитина не може відвідувати звичайну школу. Дитина може потребувати спеціалізованого навчання, що може вимагати розтавання 3 дитиною. Або ж потреба буде в налагодженні інклюзивного навчання. Сім'я уже не може замикатись у своїх рамках, а змушена контактувати та взаємодіяти 3 оточенням, що може бути стресово, оскільки в Україні не завжди можуть забезпечити адекватне навчання для дітей з особливими потребами.

4. Підлітковий вік. Батьки неповносправної дитини розуміють, що вона на все життя залишиться залежною від батьків та їх опіки; складнішим стає догляд за дитиною, оскільки, підлітковість, це вік швидких фізичних змін.

5.Дорослішання. Коли шкільне навчання завершується перед батьками постає нелегкий вибір, а куди ж далі. Це супроводжується тривогою батьків за майбутне їх дітей.

6.Доросле життя. На цій стадії сім'ю хвилюють питання, де буде жити доросла дитина з обмеженими можливостями, і який догляд їй потрібен. Батьків хвилює питання, хто доглядатиме за дитиною, коли вони будуть невзмозі це робити, або коли вони помруть.

Тому важливо розуміти, що коли ми говоримо про сім'ю, де є особлива дитина, то всі учасники взаємодії, які надають підтримку, повинні пристосовуватись до її потреб [6]. Адаптація членів сім'ї буває настільки значна, що це дуже впливає на їх особисту долю. Дитина росте, i механізми пристосування також змінюються; стрес також може по різному впливати на сім'ю в різні періоди та на різних етапах.

Велика кількість бар'єрів, 3 якими стикається сім'я дитини 3 неповносправністю в Україні, звичайно, вражає. В першу чергу, це ставлення суспільства до таких сімей. Їх не помічають, ігнорують, батьки, часто, змушені самостійно та за свій кошт здійснювати реабілітаційні заходи. Нерозвинутість соціальної інфраструктури, відсутність технічних засобів і пристосувань часто призводять до формування емоційного бар'єру таких сімей. Хоча варто зазначити, що цей бар'єр носить двосторонній характер. Оскільки такі сім'ї, зазвичай, самі прагнуть ізоляції, зменшують свої соціальні контакти та комунікацію, випадають 3 трудового колективу. 
Висновки. Психологія та інші науки по відношенню до особливих дітей та їх родин застосовують сімейно-орієнтований підхід. Спеціалісти, які працюють в цьому напрямку використовують свої знання та втручання на багатьох рівнях, i не лише на сімейному, а й на соціальному рівні [8]. Це складна праця, коли необхідно допомагати сім'ї прийняти той факт, що змінити щось неможливо. Найважче захищати інтереси сім'ї, коли вона зневірилась, ізолювалась, коли вороже налаштована. Та психолог, який консультує таку сім'ю, повинен допомогти віднайти той внутрішній ресурс, потенціал, який допоможе родині нормально функціонувати та виховувати особливу дитину. Життя - це довгий ланцюжок подій. Кожна подія несе за собою урок, і як правило, має початок, продовження та завершення. Та, коли ми говоримо про появу дитини 3 неповносправністю чи важкими хронічними недугами, то травматичний досвід стає безперервним. Залишивши таку родину без підтримки суспільства, ми можемо спостерігатись значне емоційне та фізичне перенавантаження членів сім'ї, зменшення адаптивності, підвищення рівня агресивності тощо. Тому успішне втручання вимагає розуміння системного підходу, та підтримки таких сімей на усіх рівнях.

\section{Лimepamypa:}

1.Грицюк I.M., Міліщук С.О. Особливості використання комплексної нейропсихологічної корекції в шкільному середовищі. Академічні студіï. Серія «Педагогіка», 2021. С.179-185

2.Грицюк I.М., Яцина Т.М. Психологічні особливості корекційної роботи в системі освіти дітей з вадами інтелекту. Актуальні проблеми практичної психологї у Волинському регіоні. Луцьк: Вежа-Друк, 2018. С.22-27.

3.Романчук О. Неповносправна дитина в сім'ї та в суспільстві. Львів : Літопис. 2008. 334 с.

4.Селігман М. Обычные семьи, особые дети. М. : Теревинф, 2019. 368 с.

5.Магдисюк Л. І., Блаватна О. Б. Психологічна допомога сім'ї, яка виховує дитину із затримкою психічного розвитку. Herald pedagogiki. Nauka i Praktyka \# 52 (02/2020): Wydawca: Sp. z o.o. «Diamond trading tour». 2020. S. 64-66.

6.Магдисюк Л. І., Федоренко Р. П. Медико-психологічне консультування: навч.-метод. посіб. Луцьк: Вежа-Друк, 2020. 332 с.

7.Baxter G. (1986). Intellectual disability : Parental perceptions and stigma as stress.Unpublished doctoral dissertation, Monash University, Victoria Australia.

8.The influence of moderate physical activities on the psychophysical state of children with minimal brain dysfunctions / I. Hrytsiuk and other. Journal of Physical Education and Sport. Romania: University of Pitesti, 2018. Vol.18. P. 1912-1918.

9.McDonald A.G., Carson K.L., Palmer D.J., Slay T. (1982) Phsicians' diagnostic information to parents of handicapped neonates. Mental Retardation, 20, 12-14.

10.Olson D.H. Russell G.S. Sprenkle D.H. (1980) Gircumplex model of marital and family systems II :Empirical studies and clinical intervention. In J.P. Vincent (Ed.), Advances in family intervention assessment and theory (Vol. 1, pp. 129-179). Greenwich, CT : JAI Press.

11.Turnbull A.P. Turnbull H.R. (1990). Families, professionals, and exceptionality (2 nd. ed.). Columbus, OH: Merrill.

\section{References:}

1.Hrytsiuk I.M. \& Milishchuk S.O. (2021). Osoblyvosti vykorystannia kompleksnoi neiropsykholohichnoi korektsii $\mathrm{v}$ shkilnomu seredovyshchi [Features of the use of complex 
neuropsychological correction in the school environment]. Akademichni studii. Seriia «Pedahohika», (pp. 179-185). [in Ukrainian].

2.Hrytsiuk I.M. \& Yatsyna T.M. (2018) Psykholohichni osoblyvosti korektsiinoi roboty v systemi osvity ditei z vadamy intelektu [Psychological features of correctional work in the education system of children with intellectual disabilities]. Aktualni problemy praktychnoi psykholohii $u$ Volynskomu rehioni. Lutsk: Vezha-Druk, (pp. 22-27). [in Ukrainian].

3. Romanchuk O. (2008). Nepovnospravna dytyna v simi ta $v$ suspilstvi. [Disabled child in the family and in society]. Lviv : Litopys. [in Ukrainian].

4. SelIgman M. Obyichnyie semi, osobyie deti (2019). [Ordinary families, special children] Moskva : Terevinf [in Russian].

5. Mahdysiuk L. I. \& Blavatna O. B. Psykholohichna dopomoha simi, yaka vykhovuie dytynu iz zatrymkoiu psykhichnoho rozvytku (2020). [Psychological help for a family raising a child with mental retardation]. Herald pedagogiki. Nauka i Praktyka. Wydawca : Sp. z o.o. «Diamond trading tour», ( pp. 66-66). [in Poland].

6. Mahdysiuk L. I. \& Fedorenko R. P. Medyko-psykholohichne konsultuvannia (2020). [Medical and psychological counseling]. Lutsk: Vezha-Druk. [in Ukrainian].

7.Baxter G. (1986). Intellectual disability : Parental perceptions and stigma as stress.Unpublished doctoral dissertation, Monash University, Victoria Australia.

8.The influence of moderate physical activities on the psychophysical state of children with minimal brain dysfunctions / I. Hrytsiuk and other. Journal of Physical Education and Sport. Romania: University of Pitesti, 2018. Vol.18. P. 1912-1918.

9.McDonald A.G., Carson K.L., Palmer D.J., Slay T. (1982) Phsicians' diagnostic information to parents of handicapped neonates. Mental Retardation, 20, 12-14.

10.Olson D.H. Russell G.S. Sprenkle D.H. (1980) Gircumplex model of marital and family systems II :Empirical studies and clinical intervention. In J.P. Vincent (Ed.), Advances in family intervention assessment and theory (Vol. 1, pp. 129-179). Greenwich, CT : JAI Press.

11.Turnbull A.P. Turnbull H.R. (1990). Families, professionals, and exceptionality (2 nd. ed.). Columbus, OH: Merrill. 